\title{
Incidence of second sarcomas: a cancer registry-based study
}

\author{
Fabio Levi • Lalao Randimbison - Manuela Maspoli-Conconi · \\ Rafael Blanc-Moya $\cdot$ Carlo La Vecchia
}

Received: 14 November 2013/Accepted: 16 January 2014/Published online: 25 January 2014

(C) Springer International Publishing Switzerland 2014

\begin{abstract}
Background In high-quality cancer registration systems, about one in eight incident cancers are second primary cancers. This is due to a combination of careful diagnostic ascertainment, shared genetic determinants, shared exposure to environmental factors and consequences of treatment for first cancer.

Methods We used data derived from the Swiss populationbased cancer Registries of Vaud and Neuchâtel, including 885,000 inhabitants.

Results Among 107,238 (52\% males) first cancers occurring between 1976 and 2010, a total of 126 second sarcomas were observed through active and passive follow-up versus 68.2 expected, corresponding to a standardized incidence ratio (SIR) of 1.85 (95\% CI 1.5-2.2). Significant excess sarcoma risks were observed after skin melanoma $(\mathrm{SIR}=3.0)$, breast cancer $(2.2)$, corpus uteri $(2.7)$, testicular
\end{abstract}

F. Levi $(\bowtie) \cdot$ L. Randimbison $\cdot$ R. Blanc-Moya

Vaud Cancer Registry and Cancer Epidemiology Unit, Institute

of Social and Preventive Medicine (IUMSP), Lausanne

University Hospital, Route de la Corniche 10, 1010 Lausanne,

Switzerland

e-mail: fabio.levi@chuv.ch

F. Levi · M. Maspoli-Conconi

Department of Health and Social Affairs, Neuchâtel Cancer

Registry, Av. des Cadolles 7, 2000 Neuchâtel, Switzerland

C. La Vecchia

Department of Epidemiology, IRCCS-Pharmacological Research

Institute "Mario Negri”, Via G. La Masa 19, 20156 Milan, Italy

C. La Vecchia

Department of Clinical Sciences and Community Health,

University of Milan, Via Venezian 1, 20133 Milan, Italy
(7.5), thyroid cancer (4.2), Hodgkin lymphoma (5.7) and leukemias (4.0). For breast cancer, the SIR was $3.4 \geq 5$ years after sarcoma diagnosis.

Conclusions The common denominator of these neoplasms is the utilization of radiotherapy in their management. Some sarcomas following breast cancer may be due to shared genetic components (i.e., in the Li-Fraumeni syndrome), as well as possibly to shared environmental factors, with sarcomas, including overweight, selected dietary and reproductive factors which are, however, too little defined for any quantitative risk assessment.

Keywords Second malignancy $\cdot$ Sarcoma · Cancer registry $\cdot$ Risk $\cdot$ Incidence

\section{Introduction}

Over recent years, in high-quality cancer registration systems, about one in eight to one in ten incident cancers are second primary cancers. These are due to careful diagnostic ascertainment following the diagnosis of a first primary (synchronous cancers), but also to shared genetic determinants as well as to exposure to environmental factors. In addition, the occurrence of several neoplasms is influenced by the therapies of the first cancer, including chemotherapy and radiotherapy [1-4]. Colorectum, breast, prostate and lymphomas are among the commonest sites with multiple primary cancers [5].

Second sarcomas have been recognized as a growing issue over the last few years [6]. Besides genetic components, little is known, however, on the causes of sarcomas, and exposure to ionizing radiation is one of the few established risk factors [79]. Soft tissue sarcomas have also been associated with breast and other cancers in the Li-Fraumeni syndrome [10]. 
In order to quantify the risk of second sarcomas following another neoplasm (i.e., second sarcomas), we considered data from the cancer Registries of the Swiss Cantons of Vaud and Neuchâtel [11-13].

\section{Materials and methods}

Data for the present report were abstracted from the Vaud and Neuchâtel Swiss Registries' files, which include all incident cases of malignant neoplasms diagnosed in the resident populations of these cantons (respectively, 713,000 and 172,000 inhabitants, according to the December 2010 National Census) [12, 13]. The registries are tumor-based, and multiple primary malignancies found in the same person are entered separately. Most cases are notified repeatedly and from different institutions, thus improving the completeness and accuracy of the registration. Both registries adhere to the rules of registration for first and second primary cancers of the International Agency for Research on Cancer (IARC) [14] and have been included in the IARC Cancer Incidence in Five Continents volumes since 1982 [15].

Population-based incidence data have been available since 1974 and include information on demographic characteristics (age, sex), primary site and morphology of the tumor according to the standard International Classification of Diseases for Oncology (ICD-O-1 and both ICD-O-1 and ICD-O-3 since 2005) $[16,17]$ and the date of diagnostic confirmation (histological or clinical diagnosis). No adequate information was available on history of radiotherapy.

Both passive and active follow-ups are recorded, and subsequent items of information are used to complete the record of already registered cases. Information from the death certificate is added to the registration file.

For the present analysis, after the exclusion of basal and squamous cell carcinomas of the skin, 107,238 (52\% males) first cancers occurring in patients diagnosed between 1976 and 2010 were considered. These subjects were followed up for the occurrence of a sarcoma, emigration or death, for a total of 453,792 person-years at risk. Calculation of expected numbers of second sarcomas was based on sex-, age- and calendar year-specific sarcoma incidence rates, multiplied by the corresponding number of person-years at risk. The significance of the observed/expected/ratios (standardized incidence ratios, SIRs) and their corresponding $95 \%$ confidence intervals (CI) was based on the Poisson distribution, or on exact test when required.

\section{Results}

Table 1 gives the number of registered first cancer cases overall according to major cancer sites, the person-years at risk and the number of second sarcomas.
Table 1 Number of registered first cancer cases according to major cancer sites, person-years at risk and number of second sarcomas Vaud and Neuchâtel, Switzerland, incidence period 1976-2010

\begin{tabular}{lrrc}
\hline $\begin{array}{l}\text { Site of first primary } \\
\text { (ICD-10) }\end{array}$ & $\begin{array}{l}\text { Number } \\
\text { of first } \\
\text { primaries }\end{array}$ & $\begin{array}{l}\text { Person- } \\
\text { years } \\
\text { at risk }\end{array}$ & $\begin{array}{l}\text { Number of } \\
\text { second } \\
\text { sarcomas }\end{array}$ \\
\hline Colorectum (C18-21) & 13,186 & 61,510 & 14 \\
Lung (C34) & 12,665 & 19,502 & 6 \\
Skin melanoma (C43) & 4,884 & 26,808 & 11 \\
Breast (C50) & 17,329 & 113,037 & 34 \\
Corpus uteri (C54) & 2,882 & 21,426 & 9 \\
Prostate (C61) & 13,142 & 57,134 & 13 \\
Testis (C62) & 1,199 & 8,902 & 6 \\
Thyroid (C73) & 1,158 & 8,690 & 4 \\
Hodgkin lymphoma (C81) & 735 & 6,277 & 3 \\
Non-Hodgkin lymphoma & 3,467 & 16,171 & 3 \\
$\quad$ C82-85) & 2,598 & 9,432 & 5 \\
Leukemias (C91-95) & 33,990 & 104,902 & 18 \\
Other and unknown sites ${ }^{\mathrm{a}}$ & 107,235 & 453,792 & $126^{\mathrm{b}}$ \\
\hline Total, all sites & & & \\
\hline
\end{tabular}

Vaud and Neuchâtel, Switzerland, incidence period 1976-2010

a Non-melanomatous skin cancers excluded

b ICD morphological codes for sarcomas: 8800-4, 8810-32, 8850-70, 8890-1, 8900-20, 8930, 8951, 8990, 9020, 9120, 9130,9140, 9180-4, 9220, 9240, 9260, 9370, 9522, 9560, 9580

Table 2 gives observed and expected numbers of sarcomas following all cancers (excluding non-melanomatous skin cancers) and following selected cancer sites, stratified by sex and in both sexes combined. A total of 126 sarcomas were observed following any previous cancer versus 68.2 expected, corresponding to a SIR of 1.85 (95\% CI 1.5-2.2). The SIR was $1.65(1.2-2.1)$ in men and 2.03 (1.6-2.6) in women. There were 34 sarcomas following a diagnosis of breast cancer versus 15.3 expected (SIR 2.22, $95 \%$ CI 1.5-3.1). Significant excess sarcoma risks were also observed following skin melanoma (11 cases, SIR 2.99, $95 \%$ CI 1.5-5.3), corpus uteri (9 cases, SIR 2.72, $95 \%$ 1.2-5.2), testicular cancer (6 cases, SIR 7.54, $95 \%$ CI 2.7-16.4), thyroid cancer (4 cases, SIR 4.24, $95 \%$ CI 1.1-1.8), Hodgkin lymphoma (3 cases, SIR 5.68, $95 \%$ CI 1.1-16.6) and leukemias (5 cases, SIR 3.98, $95 \%$ CI 1.3-9.3). There were 14 sarcomas following colorectal cancer versus 10.2 expected $(\mathrm{SIR}=1.38)$, six following lung cancer $(\mathrm{SIR}=2.05), 13$ following prostate cancer $(\mathrm{SIR}=1.13)$, and three following non-Hodgkin lymphomas $(\mathrm{SIR}=1.3)$. None of these estimates was significant. Following all other cancers combined, there were 18 observed sarcomas versus 15.5 expected, corresponding to a SIR of 1.2 (95\% CI 0.7-1.8).

Table 3 gives observed and expected numbers of sarcomas following colorectal, skin (melanoma), breast and all cancers in strata of time since original cancer diagnosis 
Table 2 Observed (O) and expected (E) sarcomas, and SIR, with corresponding $95 \%$ CI, by sex, among 107,238 patients diagnosed with a first cancer. Vaud and Neuchâtel, Switzerland, incidence period 1976-2010

\begin{tabular}{|c|c|c|c|c|}
\hline $\begin{array}{l}\text { Site of first primary (ICD- } \\
\text { 10) }\end{array}$ & Sex & $\mathrm{O}$ & $\mathrm{E}$ & $\operatorname{SIR}(95 \% \mathrm{CI})$ \\
\hline Colorectum (C18-21) & $\mathrm{M} \& \mathrm{~F}$ & 14 & 10.15 & $1.38(0.7-2.3)$ \\
\hline Lung (C34) & $\mathrm{M} \& \mathrm{~F}$ & 6 & 2.93 & $2.05(0.7-4.4)$ \\
\hline Skin melanoma (C43) & $\mathrm{M} \& \mathrm{~F}$ & 11 & 3.68 & $2.99(1.5-5.3)$ \\
\hline Breast (C50) & $\mathrm{F}$ & 34 & 15.30 & $2.22(1.5-3.1)$ \\
\hline Corpus uteri (C54) & $\mathrm{F}$ & 9 & 3.30 & $2.72(1.2-5.2)$ \\
\hline Prostate (C61) & M & 13 & 11.55 & $1.13(0.6-1.9)$ \\
\hline Testis (C62) & M & 6 & 0.80 & $7.54(2.7-16.4)$ \\
\hline Thyroid (C73) & $\mathrm{M} \& \mathrm{~F}$ & 4 & 0.94 & $4.24(1.1-1.8)$ \\
\hline Hodgkin lymphoma (C81) & $\mathrm{M} \& \mathrm{~F}$ & 3 & 0.53 & $5.68(1.1-16.6)$ \\
\hline $\begin{array}{l}\text { Non-Hodgkin lymphoma } \\
\text { (C82-85) }\end{array}$ & $M \& F$ & 3 & 2.30 & $1.31(0.3-3.8)$ \\
\hline Leukemias (C91-95) & $\mathrm{M} \& \mathrm{~F}$ & 5 & 1.26 & $3.98(1.3-9.3)$ \\
\hline Other and unknown sites ${ }^{\mathrm{a}}$ & $\mathrm{M} \& \mathrm{~F}$ & 18 & 15.46 & $1.16(0.7-1.8)$ \\
\hline \multirow[t]{3}{*}{ Total, all sites ${ }^{\mathrm{a}}$} & M & 55 & 33.30 & $1.65(1.2-2.1)$ \\
\hline & $\mathrm{F}$ & 71 & 34.90 & $2.03(1.6-2.6)$ \\
\hline & $M \& F$ & $126^{\mathrm{b}}$ & 68.21 & $1.85(1.5-2.2)$ \\
\hline
\end{tabular}

${ }^{a}$ Non-melanomatous skin cancers excluded

b ICD morphological codes for sarcomas: 8800-4, 8810-32, $8850-70,8890-1,8900-20,8930,8951,8990,9020,9120$, $9130,9140,9180-4,9220,9240,9260,9370,9522,9560,9580$

( $<5$ vs. $\geq 5$ years) and age at diagnosis of second sarcoma ( $<70$ vs. $\geq 70$ years). The excess risk became significant five or more years after breast cancer diagnosis (SIR 3.4, $95 \%$ CI 2.2-4.9). No such pattern of risk with passing time was observed for any other major cancer considered. With reference to all cancers, the SIRs were $1.61(95 \% \mathrm{CI}$ 1.2-2.1) under five years and 2.11 (95\% CI 1.6-2.7) five years or more following the diagnosis of the first primary. With reference to age at diagnosis of second sarcomas, all the SIRs were somewhat higher at age $\geq 70$, in the absence, however, of heterogeneity. For all neoplasms, the SIRs were 1.59 at age $<70$ versus 2.25 at age $\geq 70$.

\section{Discussion}

The present, population-based study provides quantitative evidence that the incidence of sarcomas is increased following a diagnosis of a number of cancer sites, including breast cancer, skin melanoma, testicular, uterine and thyroid cancers, Hodgkin lymphoma and leukemias. The common denominator of these neoplasms is the widespread utilization of radiotherapy in their management. These data, therefore, provide additional and definite evidence
Table 3 Observed (O) and expected (E) sarcomas, and SIRs, with corresponding $95 \% \mathrm{CI}$, by time since diagnosis of selected first major neoplasm and by age at diagnosis of second sarcoma. Vaud and Neuchâtel, Switzerland, incidence period 1976-2010

\begin{tabular}{|c|c|c|c|c|}
\hline \multirow[t]{2}{*}{$\begin{array}{l}\text { Site of first primary } \\
\text { (ICD-10) }\end{array}$} & \multicolumn{2}{|c|}{$\begin{array}{l}\text { Time since first } \\
\text { neoplasm }\end{array}$} & \multicolumn{2}{|c|}{$\begin{array}{l}\text { Age at diagnosis of } \\
\text { second sarcoma }\end{array}$} \\
\hline & $\begin{array}{l}<5 \text { years } \\
\text { O/E } \\
\text { SIR } \\
(95 \% \\
\text { CI })\end{array}$ & $\begin{array}{l}\geq 5 \text { years } \\
\text { O/E } \\
\text { SIR } \\
(95 \% \\
\text { CI })\end{array}$ & $\begin{array}{l}<70 \text { years } \\
\text { O/E } \\
\text { SIR } \\
(95 \% \mathrm{CI})\end{array}$ & $\begin{array}{l}\geq 70 \text { years } \\
\text { O/E } \\
\text { SIR } \\
(95 \% \mathrm{CI})\end{array}$ \\
\hline $\begin{array}{l}\text { Colorectum } \\
\text { (C18-21) }\end{array}$ & $\begin{array}{l}7 / 5.3 \\
1.32 \\
(0.5-2.7)\end{array}$ & $\begin{array}{l}7 / 4.8 \\
1.45 \\
(0.6-3.0)\end{array}$ & $\begin{array}{l}6 / 5.3 \\
1.14 \\
(0.4-2.5)\end{array}$ & $\begin{array}{l}8 / 4.9 \\
1.64 \\
(0.7-3.2)\end{array}$ \\
\hline $\begin{array}{l}\text { Skin melanoma } \\
\text { (C43) }\end{array}$ & $\begin{array}{l}6 / 1.7 \\
3.50 \\
(1.3-7.6)\end{array}$ & $\begin{array}{l}5 / 2.0 \\
2.54 \\
(0.8-5.9)\end{array}$ & $\begin{array}{l}6 / 2.5 \\
2.38 \\
(0.9-5.2)\end{array}$ & $\begin{array}{l}5 / 1.2 \\
4.33 \\
(1.4-10.1)\end{array}$ \\
\hline Breast (C50) & $\begin{array}{l}7 / 7.3 \\
0.97 \\
(0.4-2.0)\end{array}$ & $\begin{array}{l}27 / 8.1 \\
3.35 \\
(2.2-4.9)\end{array}$ & $\begin{array}{l}18 / 10.5 \\
1.71 \\
(1.0-2.7)\end{array}$ & $\begin{array}{l}16 / 4.8 \\
3.36 \\
(1.9-5.5)\end{array}$ \\
\hline Total, all sites ${ }^{\mathrm{a}}$ & $\begin{array}{l}58 / 36.0 \\
1.61 \\
(1.2-2.1)\end{array}$ & $\begin{array}{l}68 / 32.2 \\
2.11 \\
(1.6-2.7)\end{array}$ & $\begin{array}{l}66 / 41.6 \\
1.59 \\
(1.2-2.1)\end{array}$ & $\begin{array}{l}60 / 26.6 \\
2.25 \\
(1.7-2.9)\end{array}$ \\
\hline
\end{tabular}

${ }^{a}$ Non-melanomatous skin cancers excluded

that the risk of sarcomas is strongly associated with ionizing radiation $[7,8]$.

Some of the excess sarcomas, moreover, may be due to shared genetic factors [5, 18]. Sarcomas, in fact, are one of the components of the Li-Fraumeni syndrome, linked to germline mutations of the TP53 tumor suppressor gene [19], characterized in its classical form by sarcomas and cancers of the breast, brain and adrenal glands. Shared environmental factors, including immune suppression, hormonal factors, height, body mass index (BMI) and related aspects of diet [7, 20-23], may also have some role on the excess sarcoma risk following another neoplasm.

Thus, immune suppression has been related to Kaposi's and also other types of cancers. In a cohort study linking data on solid organ transplant recipients from the US Scientific Registry of Transplant Recipients over the period 1987-2008 with 13 states and regional cancer registries, and including 175,732 solid organ transplants, the SIRs were 2.25 (95\% CI 1.74-2.87) for soft tissue sarcomas including heart (65 cases) and 1.98 (95\% CI, 1.09-3.33) for bone and joints (14 cases) [24]. Late age at first pregnancy and birth, a recognized risk factor for breast cancer, has been associated with excess risk of sarcomas [20]. In an Italian case-control study, the relative risk (RR) was over three for BMI $\geq 30$ versus $<20$ [22], and overweight and obesity were related to colorectal, breast, endometrial 
cancer, lymphoma and several other neoplasms [25-28]. In a companion study [21], whole grain was inversely related to the risk of soft tissue sarcomas, whereas selected foods rich in animal fats tended to be positively associated. This is compatible with our knowledge on favorable and unfavorable dietary patterns on the risk of several neoplasms [29, 30]. These factors, however, are too poorly defined and quantified in relation to sarcoma risk to provide any clue for the interpretation of the present results.

A major advantage of these Swiss datasets is that, in the populations considered, there is a long tradition of valid and accurate cancer registration (confirmed by the inclusion of incidence data in the last seven quinquennial issues of the IARC/WHO series Cancer Incidence in five Continents) $[12,13]$, as well as of systematic examination of all surgically treated lesions, including skin melanomas [11, $31]$, thus adding validity to the present results.

Acknowledgments The work of C.L.V. was supported by the Italian Association for Research on Cancer (AIRC, Contract No. 10068). The authors wish to thank Mrs. I. Garimoldi for editorial assistance.

Conflict of interest The authors declare that they have no conflict of interest.

\section{References}

1. Levi F, Randimbison L, Te VC, Rolland-Portal I, Franceschi S, La Vecchia C (1993) Multiple primary cancers in the Vaud Cancer Registry, Switzerland, 1974-89. Br J Cancer 67:391-395

2. Levi F, Randimbison L, Te VC, La Vecchia C (2006) Cancer risk after radiotherapy for breast cancer. Br J Cancer 95:390-392

3. Levi F, Randimbison L, Blanc-Moya R, Maspoli-Conconi M, La Vecchia C (2014) Second primary cancers in the Vaud and Neuchatel cancer registries. Eur J Cancer Prev (in press)

4. Travis LB (2006) The epidemiology of second primary cancers. Cancer Epidemiol Biomarkers Prev 15:2020-2026

5. Teerlink CC, Albright FS, Lins L, Cannon-Albright LA (2012) A comprehensive survey of cancer risks in extended families. Genet Med 14:107-114

6. Bjerkehagen B, Smastuen MC, Hall KS, Skjeldal S, Bruland OS, Smeland S, Johannesen TB, Fossa SD (2013) Incidence and mortality of second sarcomas-a population-based study. Eur J Cancer 49:3292-3302

7. Berwick M (2006) Soft tissue sarcoma. In: Schottenfeld D, Fraumeni JF (eds) Cancer epidemiology and prevention. Oxford University Press, New York, pp 959-974

8. Mark RJ, Poen J, Tran LM, Fu YS, Selch MT, Parker RG (1994) Postirradiation sarcomas. A single-institution study and review of the literature. Cancer 73:2653-2662

9. Serraino D, Franceschi S, Talamini R, Frustaci S, La Vecchia C (1991) Non-occupational risk factors for adult soft-tissue sarcoma in northern Italy. Cancer Causes Control 2:157-164

10. Li FP, Fraumeni JF Jr (1969) Soft-tissue sarcomas, breast cancer, and other neoplasms. A familial syndrome? Ann Intern Med 71:747-752

11. Levi F, La Vecchia C, Randimbison L, Te VC (1999) Descriptive epidemiology of soft tissue sarcomas in Vaud, Switzerland. Eur J Cancer 35:1711-1716
12. Levi F, Te VC, Blanc-Moya R, Randimbison L, Choffat R (2013) Cancer Incidence in Vaud (2003-2007). In: Forman D, Bray F, Brewster DH, Gombe Mbalawa C, Kohler B, Piñeros M, Steliarova-Foucher E, Swaminathan R and Ferlay J (eds). Cancer incidence in five continents, vol $\mathrm{X}$ (electronic version). IARC, Lyon. (last accessed November 2013) http://ci5.iarc.fr

13. Levi F, Maspoli-Conconi M, Choffat R, Randimbison L (2013) Cancer incidence in Neuchâtel (2003-2007). In: Forman D, Bray F, Brewster DH, Gombe Mbalawa C, Kohler B, Piñeros M, Steliarova-Foucher E, Swaminathan R and Ferlay J (eds) Cancer incidence in five continents, vol X (electronic version). IARC, Lyon. (Last Accessed Nov 2013) http://ci5.iarc.fr

14. Working group report IARC (2005) International rules for multiple primary cancers (ICD-0 third edition). Eur J Cancer Prev 14:307-308

15. Levi F, Delachaux A, Junod B, Wietlisbach V (1982) Cancer incidence in Vaud, Switzerland (1975-1977). In: Waterhouse J, Muir C, Shanmugaratnam K, Powell J (eds) Cancer incidence in five continents, vol IV. IARC Scientific Publications No. 42. IARC, Lyon, pp 546-549

16. World Health Organization (1976) International classification of diseases for oncology. World Health Organization, ICD-O, Geneva, p 131

17. World Health Organization (2000) International classification of diseases for oncology, 3rd edn. World Health Organization, Geneva, p 240

18. Turati F, Negri E, Vecchia CL (2014) Family history and the risk of cancer: genetic factors influencing multiple cancer sites. Expert Rev Anticancer Ther 14:1-4

19. Varley JM (2003) Germline TP53 mutations and Li-Fraumeni syndrome. Hum Mutat 21:313-320

20. Fioretti F, Tavani A, Gallus S, Negri E, Franceschi S, La Vecchia C (2000) Menstrual and reproductive factors and risk of soft tissue sarcomas. Cancer 88:786-789

21. Tavani A, Pregnolato A, Negri E, Franceschi S, Serraino D, Carbone A, La Vecchia C (1997) Diet and risk of lymphoid neoplasms and soft tissue sarcomas. Nutr Cancer 27:256-260

22. Tavani A, Soler M, La Vecchia C, Negri E, Gallus S, Franceschi S (1999) Body weight and risk of soft-tissue sarcoma. Br J Cancer 81:890-892

23. Zahm SH, Blair A, Holmes FF, Boysen CD, Robel RJ, Fraumeni JF Jr (1989) A case-control study of soft-tissue sarcoma. Am J Epidemiol 130:665-674

24. Engels EA, Pfeiffer RM, Fraumeni JF Jr, Kasikse BL, Israni AK, Snyder JJ, Wolfe RA, Goordich NP, Bayakli AR, Clarke CA, Copeland G, Finch JL, Fleissner ML, Goodman MT, Kahn A, Koch L, Lynch CF, Madeleine MM, Pawlish K, Rao C, Williams MA, Castenson D, Curry M, Parsons R, Fant G, Lin M (2011) Spectrum of cancer risk among US solid organ transplant recipients. JAMA 306:1891-1901

25. Calle EE, Rodriguez C, Walker-Thurmand K, Thun MJ (2003) Overweight, obesity, and mortality from cancer in a prospectively studied cohort of US adults. N Engl J Med 348:1625-1638

26. La Vecchia C, Negri E, Franceschi S, Talamini R, Bruzzi P, Palli D, Decarli A (1997) Body mass index and post-menopausal breast cancer: an age-specific analysis. Br J Cancer 75:441-444

27. Russo A, Franceschi S, La Vecchia C, Dal Maso L, Montella M, Conti E, Giacosa A, Falcini F, Negri E (1998) Body size and colorectal cancer risk. Int J Cancer 78:161-165

28. Rosato V, Zucchetto A, Bosetti C, Dal Maso L, Montella M, Pelucchi C, Negri E, Franceschi S, La Vecchia C (2011) Metabolic syndrome and endometrial cancer risk. Ann Oncol 22:884-889

29. Bosetti C, Pelucchi C, La Vecchia C (2009) Diet and cancer in Mediterranean countries: carbohydrates and fats. Publ Health Nutr 12:1595-1600 
30. Giacosa A, Barale R, Bavaresco L, Gatenby P, Gerbi V, Janssens J, Johnston B, Kas K, La Vecchia C, Mainguet P, Morazzoni P, Negri E, Pelucchi C, Pezzotti M, Rondanelli M (2013) Cancer prevention in Europe: the Mediterranean diet as a protective choice. Eur J Cancer Prev 22:90-95
31. Levi F, Te VC, Randimbison L, La Vecchia C (2005) Trends in incidence of various morphologies of malignant melanoma in Vaud and Neuchatel, Switzerland. Melanoma Res 15:73-75 